\title{
Comparative Study of Steel and Glass Fiber Reinforced Concrete Composites
}

\author{
Tejas R Patil ${ }^{1}$, Ajay N. Burile ${ }^{2}$ \\ Department of Civil Engineering, Priyadarshini Bhagwati College of Engineering, Nagpur-24, Maharashtra, India
}

\begin{abstract}
Concrete is most widely used construction material in the world. Fiber reinforced concrete (FRC) is a concrete in which small and discontinuous fibers are dispersed uniformly. The fibers used in FRC may be of different materials like steel, G.I., carbon, glass, aramid, asbestos, polypropylene, jute etc. The addition of these fibers into concrete mass can dramatically increase the compressive strength, tensile strength, flexural strength and impact strength of concrete. FRC has found many applications in civil engineering field. Based on the laboratory experiment on fiber reinforced concrete (FRC), cube and cylinders specimens have been designed with steel fiber reinforced concrete (SFRC) containing fibers of $0 \%$ and $0.5 \%$ volume fraction of hook end Steel fibers of 53.85, 50 aspect ratio and alkali resistant glass fibers containing $0 \%$ and $0.25 \%$ by weight of cement of $12 \mathrm{~mm}$ cut length were used without admixture. Comparing the result of FRC with plain M20 grade concrete, this paper validated the positive effect of different fibers with percentage increase in compression and splitting improvement of specimen at 7 and 28 days, analyzed the sensitivity of addition of fibers to concrete with different strength
\end{abstract}

Keywords: Compressive Strength, Fiber Reinforced Concrete, Glass Fibers, Split Tensile Strength, Steel Fibers

\section{Introduction}

Cement concrete is characterized by brittle failure, the nearly complete loss of loading capacity, once failure is initiated. This characteristic, which limits the application of the material, can be overcome by the inclusion of a small amount of short randomly distributed fibers (steel, glass, synthetic and natural) and can be practiced among others that remedy weaknesses of concrete, such as low growth resistance, high shrinkage cracking, low durability, etc

The strength and durability of concrete can be changed by making appropriate changes in its ingredients like cemetitious material, aggregate and water and by adding some special ingredients. Hence concrete is very well suited for a wide range of applications. However concrete has some deficiencies as low tensile strength, low post cracking capacity, brittleness and low ductility, limited fatigue life, not capable of accommodating large deformations, low impact strength

The presence of micro cracks at the mortar-aggregate interface is responsible for the inherent weakness of plain concrete. The weakness can be removed by inclusion of fibers in the mix Different types of fibers, such as those used in traditional composite materials have been introduced into the concrete mixture to increase its toughness, or ability to resist crack growth. The fibers help to transfer loads at the internal micro cracks. Such a concrete is called fiberreinforced concrete (FRC). Thus fiber-reinforced concrete is a composite material essentially consisting of conventional concrete or mortar reinforced by fine fibers

The fibers can be imagined as an aggregate with an extreme deviation in shape from the rounded smooth aggregate. The fibers interlock and entangle around aggregate particles and considerably reduce the workability, while the mix becomes more cohesive and less prone to segregation. The fibers are dispersed and distributed randomly in the concrete during mixing and thus improve concrete properties in all directions. Fibers help to improve the post peak ductility performance, pre-crack tensile strength, fatigue strength, impact strength and eliminate temperature and shrinkage cracks

Essentially, fibers act as crack arrester restricting the development of cracks and thus transforming an inherently brittle matrix, i.e. cement concrete with its low tensile and impact resistances, into a strong composite with superior crack resistance, improved ductility and distinctive postcracking behavior prior to failure

Hence, this study explores the feasibility of used of metallic and synthetic fibers; aim to do parametric study on compressive strength, tensile strength study etc. for a given grade of concrete, aspect ratio and various percentages of fibers.

\section{Literature Survey}

Presently, a number of laboratory experiments on mechanical properties of SFRC have been done. Shah Surendra and Rangan], in their investigations conducted uniaxial compression test on fiber reinforced concrete specimens. The results shown the increase in strength of $6 \%$ to $17 \%$ compressive strength, $18 \%$ to $47 \%$ split tensile strength, $22 \%$ to $63 \%$ flexural strength and $8 \%$ to $25 \%$ modulus of elasticity respectively. Byung Hwan Oh in their investigations, the mechanical properties of concrete have been studied, these results shown the increase in strength of $6 \%$ to $17 \%$ compressive strength, $14 \%$ to $49 \%$ split tensile strength, $25 \%$ to $55 \%$ flexural strength and $13 \%$ to $27 \%$ modulus of elasticity respectively. Barrows and Figueiras in their investigations the mechanical properties of concrete have been studied. These results shown the increase in strength of $7 \%$ to $19 \%$ compressive strength, $19 \%$ to $48 \%$ split tensile strength, $25 \%$ to $65 \%$ flexural strength and $7 \%$ to $25 \%$ modulus of elasticity respectively. Chen $\mathrm{S}$. investigated the strength of 15 steel fiber reinforced and plain concrete ground slabs. The slabs were $2 \times 2 \times 0.12 \mathrm{~m}$, 


\section{International Journal of Science and Research (IJSR) \\ ISSN (Online): 2319-7064 \\ Index Copernicus Value (2013): 6.14 | Impact Factor (2015): 6.391}

reinforced with hooked end steel fibers and mill cut steel fibers. Dwaraknath and Nagaraj predicted flexural strength of steel fiber concrete by these parameters such as direct tensile strength, split cylinder strength and cube strength. James and Beaudoin stated that the minimum fiber volume dosage rate for steel, glass and polypropylene fibers in the concrete matrix was calculated approximately $0.31 \%, 0.40 \%$ and $0.75 \%$. Patton and Whittaker investigated on steel fiber concrete for dependence of modulus of elasticity and correlation changes on damage due to load. Rossi et. al, analyzed that the effects of steel fibers on the cracking at both local level (behavior of steel fibers) and global level (behavior of the fiber/cement composite) were dependent to each other. Sener et. alcalibrated the size effect of the 18 concrete beams under four-point loading. Swami and Saad], had done an investigation on deformation and ultimate strength of flexural in the reinforced concrete beams under 4 point loading with the usage of steel fibers, where consists of 15 beams (dimensions of $130 \times 203 \times 2500 \mathrm{~mm}$ ) with same steel reinforcement (2Y-10 top bar and 2Y-12 bottom bar) and variables of fibers volume fraction $(0 \%, 0.5 \%$ and $1.0 \%)$. Tan et. al [9] concluded some investigation on the shear behavior of steel fiber reinforced concrete. Six simply supported beams were tested under two- point loading with hooked steel fibers of $30 \mathrm{~mm}$ long and $0.5 \mathrm{~mm}$ diameter, as the fiber volume fraction increased every $0.25 \%$ from $0 \%$ to $1.0 \%$. Vandewalle had done a similar crack behavior investigation, which based on combination of five full scale reinforced concrete beams $(350 \times 200 \times 3600 \mathrm{~mm})$ with steel fibers (volume fraction of $0.38 \%$ and $0.56 \%$ ). In his investigation, the experimental results and theoretical prediction on the crack width was compared.

\section{Experimental Program}

\section{A. Material Used}

Cement, sand, coarse aggregate, water, steel and glass fibers were used.

Cement: The cement used was Ordinary Portland cement (43 Grade) with a specific gravity of 3.15. Initial and final setting time of the cement was $20 \mathrm{~min}$ and $227 \mathrm{~min}$, respectively. Ordinary Portland cement of 43 grade was used, conforming to I.S-8112- 1989

Sand: Good quality river sand was used as a fine aggregate. Locally available sand, confirming to zone II with specific gravity 2.45 , water absorption $2 \%$ and fineness modulus 3.18, conforming to I.S. $-383-1970$

Coarse aggregate: Crushed granite stones of maximum 20 $\mathrm{mm}$ size having specific gravity of 2.67 , fineness modulus of 7.10 , conforming to IS $383-1970$

Water: Potable water was used for the experimentation.

Fibers: In this work, effects on strength of concrete with two hook end steel fibers and alkali resistance glass fibers at low volume fraction were studied.

Mild steel wire form, Hook end $35 \mathrm{~mm}$ and $50 \mathrm{~mm}$ length having density of $7.85 \mathrm{~g} / \mathrm{cm}_{3}$ and minimum tensile strength as $345 \mathrm{MPa}$, at $0.5 \%$ by volume of concrete collected from
Stewols Pvt. Ltd. Nagpur, Maharashtra, India, were used. The different aspect ratios adopted were 53.85 and 50 with diameter of fibers 0.93 and $0.7 \mathrm{~mm}$ respective. Physical Properties of used fibers were shown in table1.

Table 1: Description of Different Fibers

\begin{tabular}{|c|c|c|c|c|}
\hline $\begin{array}{c}\text { Fibre } \\
\text { Designation }\end{array}$ & $\begin{array}{c}\text { Length } \\
(\mathrm{mm})\end{array}$ & Description & $\begin{array}{c}\text { Dosage of } \\
\text { Fibers }\end{array}$ & $\begin{array}{c}\text { Aspect } \\
\text { Ratio } \\
(\mathrm{L} / \mathrm{D})\end{array}$ \\
\hline S1 (Steel) & 50 & Hook End & $0.5 \%$ by vol & 53.85 \\
\hline S2 (Steel) & 35 & Hook End & $0.5 \%$ by vol & 50 \\
\hline G (Glass) & 12 & $\begin{array}{c}\text { Alkali } \\
\text { Resistance }\end{array}$ & $0.25 \%$ by wt & ---- \\
\hline
\end{tabular}

\section{B. Concrete Mix Proportions}

The mixture proportioning was done according the Indian Standard Recommended Method IS 10262- 2009[20] and with reference to IS 456-2000 [19]. The target mean strength was $26 \mathrm{MPa}$ for the OPC control mixture, the total binder content was $383 \mathrm{Kg} / \mathrm{m} 3$, fine aggregate was taken $672 \mathrm{Kg} /$ $\mathrm{m}_{3}$ and coarse aggregate was taken $1100 \mathrm{Kg} / \mathrm{m} 3$. The water to binder ratio was kept constant as 0.5 . The total mixing time was 5 minutes, the samples were then casted and left for $24 \mathrm{hrs}$ before demoulding. They were then placed in the curing tank until the day of testing cement, sand and coarse aggregate were properly mixed together in the ratio 1:1.75:2.87 by weight before water was added and properly mixed together to achieve homogenous material. Water absorption capacity and moisture content were taken into consideration. Cube and cylindrical moulds were used for casting. Compaction of concrete in three layers with 25 strokes of $16 \mathrm{~mm}$ rod was carried out for each layer. The concrete was left in the mould and allowed to set for 24 hours before the specimens were demoulded and placed in curing tank. The specimens with and without fiber were cured in the tank for 7 and 28days.

Concrete for M20 grade were prepared as per I.S.10262:2009 with w/c 0.5

Table 2: Details of Quantity of Constituent Materials

\begin{tabular}{|c|c|c|}
\hline Material & Quantity & Proportion \\
\hline Cement & $383 \mathrm{Kg} / \mathrm{m}_{3}$ & 1 \\
\hline Sand & $672 \mathrm{Kg} / \mathrm{m}_{3}$ & 1.75 \\
\hline Coarse Aggregates $(20 \mathrm{~mm})$ & $1100 \mathrm{Kg} / \mathrm{m}_{3}$ & 2.87 \\
\hline Water & $192 \mathrm{Kg} / \mathrm{m}_{3}$ & 0.5 \\
\hline
\end{tabular}

It have been performed to determine the mechanical properties such as compressive strength and splitting tensilestrength of concrete mix with steel fibers $0 \%, 0.5 \%$ by volume of concrete and alkali resistance glass fibers, $0.25 \%$ by weight of cement.

\section{Compressive Strength Test}

The strength of concrete is usually defined and determined by the crushing strength of $150 \mathrm{~mm} \times 150 \mathrm{mmx} 150 \mathrm{~mm}$, at an age of 7 and 28days. It is most common test conducted on hardened concrete as it is an easy test to perform and also most of the desirable characteristic properties of concrete are qualitatively related to its compressive strength. Steel mould made of cast iron dimension $150 \mathrm{~mm} \times 150 \mathrm{~mm} \times 150 \mathrm{~mm}$ used for casting of concrete cubes filled with steel fibers $0 \%, 0$. $5 \%$ by volume of concrete and alkali resistance glass fibers, $0 \%$ and $0.25 \%$ by weight of cement. The mould and its base rigidly damped together so as to reduce leakages during 


\section{International Journal of Science and Research (IJSR) \\ ISSN (Online): 2319-7064 \\ Index Copernicus Value (2013): 6.14 | Impact Factor (2015): 6.391}

casting. The sides of the mould and base plates were oiled before casting to prevent bonding between the mould and concrete. The cube was then stored for 24 hours undisturbed at temperature of $18^{\circ} \mathrm{C}$ to $22^{\circ} \mathrm{C}$ and a relative humidity of not less than $90 \%$ (IS 516-1959).

It also stated in IS 516-1959 that the load was applied without shock and increased continuously at the rate of approximately $140 \mathrm{Kg} / \mathrm{sq} \mathrm{cm} / \mathrm{min}$ until the resistance of specimen to the increasing loads breaks down and no greater load can be sustained. The maximum load applied to the specimen was then recorded as per IS: 516-1959. The testing of cube and cylinders under compression were shown in figure 1 .

The compressive strength was calculated as follows:

Compressive strength $(\mathrm{MPa})=$ Failure load $/$ cross sectional area.

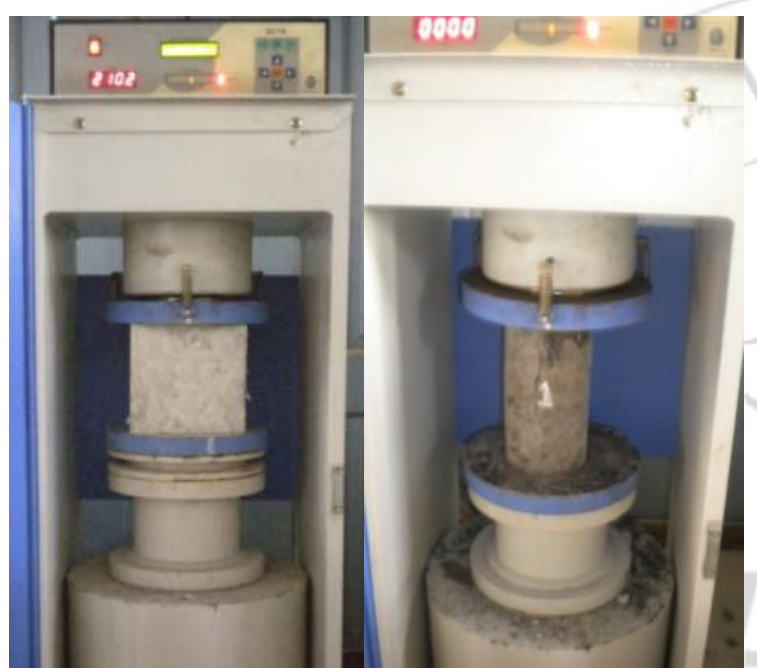

Figure 1: Compression Test on Cube and Cylinders

\section{Split Tensile Strength Test}

The test was conducted as per IS 5816:1999 For tensile strength test, cylindrical specimens of dimension $100 \mathrm{~mm}$ diameter and $200 \mathrm{~mm}$ length were cast. The specimens were demoulded after 24 hours of casting and were transferred to curing tank where in they were allowed to cure for 7 and 28 days. In each category, three cylinders were tested and their average value was reported [10]. The split tension test was conducted as shown in figure 2 using digital compression machine having $2000 \mathrm{kN}$ capacity.

Split tensile strength was calculated as follows:

Spilt Tensile strength $(\mathrm{MPa})=2 \mathrm{P} / \pi \mathrm{DL}$

Where, $\mathrm{P}=$ Failure Load $(\mathrm{kN})$

$\mathrm{D}=$ Diameter of Specimen $(100 \mathrm{~mm})$

$\mathrm{L}=$ Length of Specimen $(200 \mathrm{~mm}$
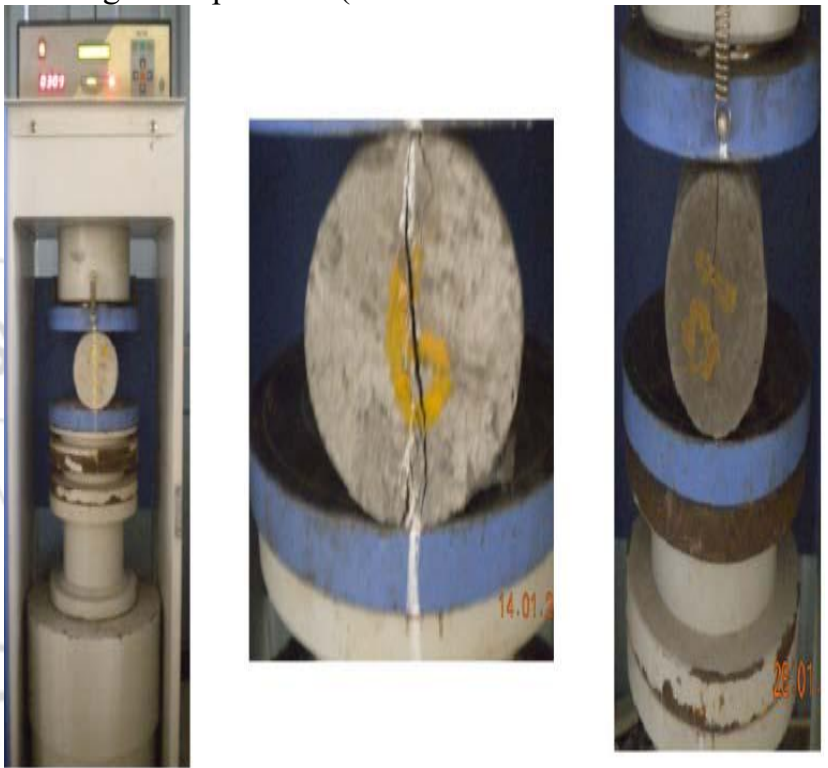

Figure 2: Cylinders under Split tension

\section{Experimental Results}

A. Compressive Strength Test Results

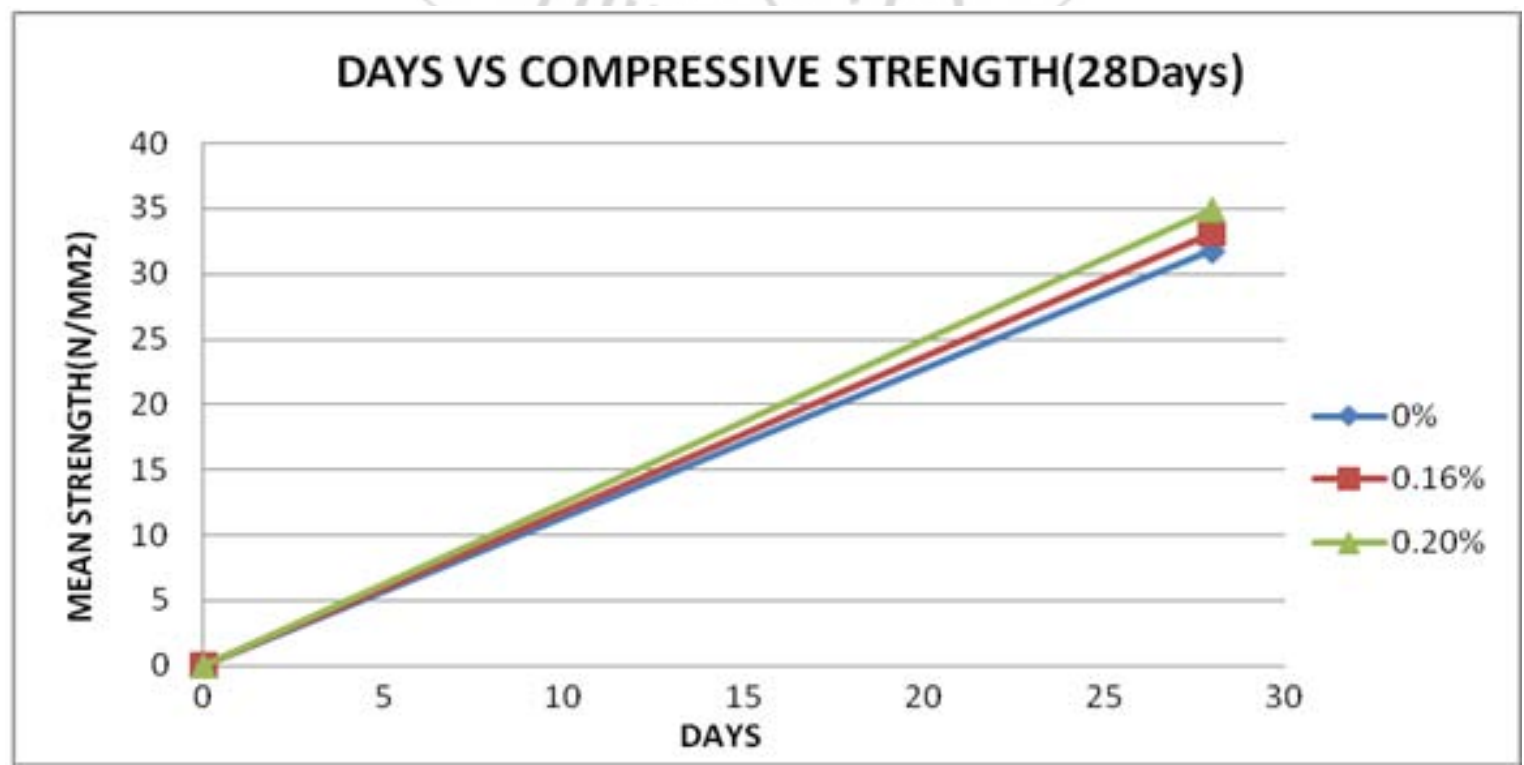

Figure 3: compressive strength using cylindrical specimen 


\section{International Journal of Science and Research (IJSR) \\ ISSN (Online): 2319-7064 \\ Index Copernicus Value (2013): 6.14 | Impact Factor (2015): 6.391}

Figure 3 indicates the results of compression test on cube for M20 grade of concrete using various fibers at different volume fractions

It was observed that, addition of $0.5 \%, 50 \mathrm{~mm}$ length, hook end steel fiber gives max compressive strength in comparison with all other fibers.

The compressive strength test is consider the most suitable method of evaluating the behavior of steel fiber reinforced concrete for underground construction at an early age, because in many cases such as in tunnels, steel fiber reinforced concrete is mainly subjected to compression.
516:1959 It is observed that when fibres in discrete form present in the concrete, propagation of crack is restrained which is due to the bonding of fibres in to the concrete and it changes its brittle mode of failure in to a more ductile one and improves the post cracking load and energy absorption capacity

Results of compressive strength for M20 grade of concrete on cube and cylinder specimens with steel fibers $0 \%, 0.5 \%$ by volume of concrete and alkali resistance glass fibers, $0.25 \%$ by weight of cement was shown in figure 3 as below

\section{Compressive Strength Using Cube}

Compressive strength of control concrete and concrete with various fibers was calculated by above formula as per I.S.

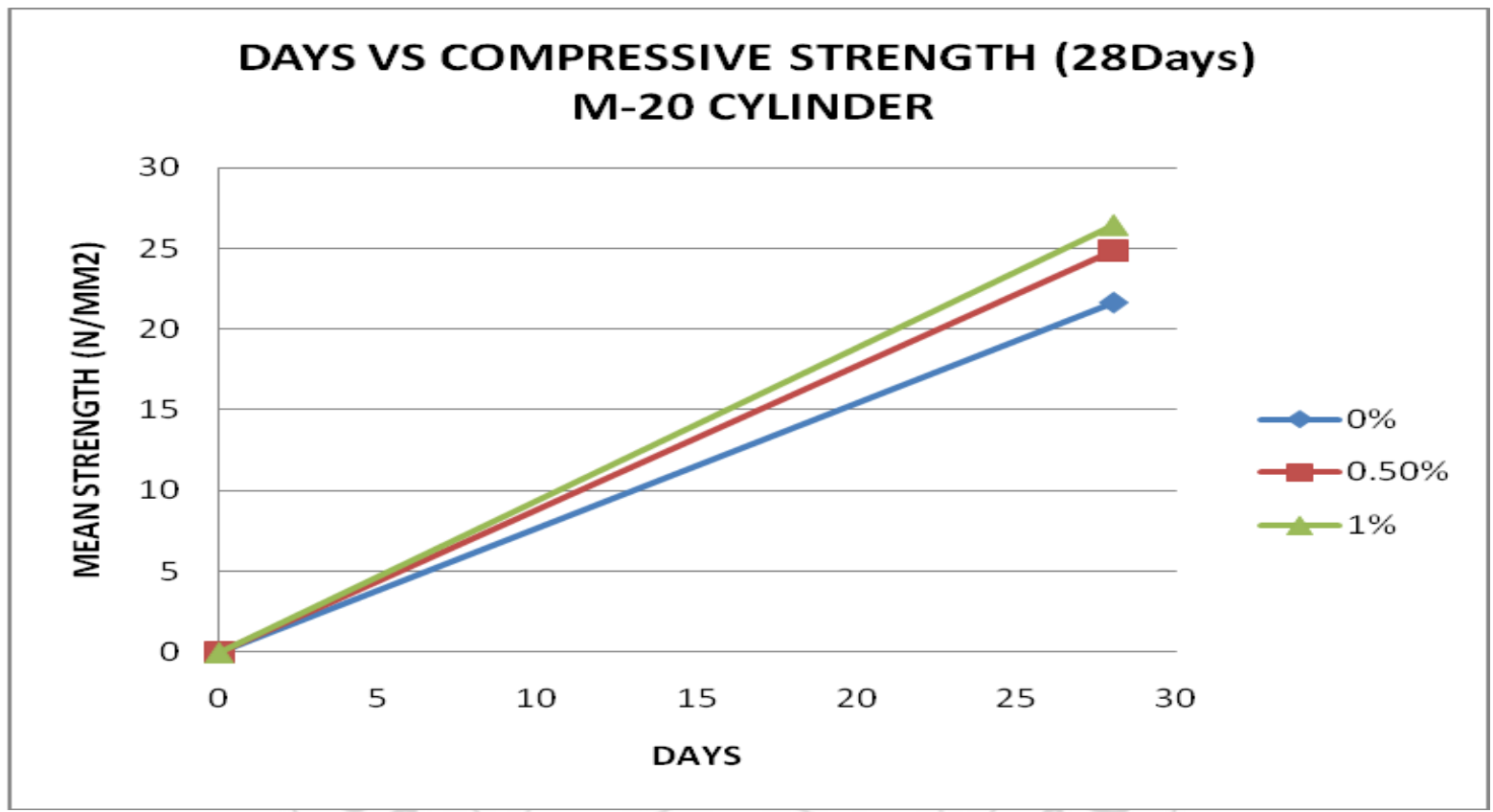

Figure 4: Compressive Strength Using Cylindrical Specimens

Figure 4 indicates the results of compression test on cylinders for M20 grade of concrete using different fibers at different volume fraction.

\section{Results of Flexural Test}

It was observed that, addition of $0.5 \%, 50 \mathrm{~mm}$ length, hook end steel fibers gives max compressive strength using cylinder specimens among all the fibers

\begin{tabular}{|c|c|c|c|c|c|c|c|c|}
\hline \multicolumn{9}{|c|}{ Flexural Test (Beams) M20 Steel fiber } \\
\hline \multirow[b]{2}{*}{ Days } & \multirow{2}{*}{$\begin{array}{c}\text { Beam } \\
\text { No }\end{array}$} & \multicolumn{3}{|c|}{$0 \%$} & \multicolumn{4}{|c|}{$0.50 \%$} \\
\hline & & $\mathrm{KN}$ & $\mathrm{Kg} / \mathrm{cm}^{2}$ & $\operatorname{Mean}\left(\mathrm{N} / \mathrm{mm}^{2}\right)$ & $\mathrm{KN}$ & $\mathrm{Kg} / \mathrm{cm}^{2}$ & $\operatorname{Mean}\left(\mathrm{N} / \mathrm{mm}^{2}\right)$ & $\begin{array}{l}\% \\
\text { Decrease }\end{array}$ \\
\hline \multirow{2}{*}{28} & 1 & 1600 & 33.18 & \multirow{2}{*}{3.39} & 1400 & 29.03 & \multirow{2}{*}{3.1} & \multirow{2}{*}{9.35} \\
\hline & 2 & 1680 & 34.84 & & 1600 & 33.19 & & \\
\hline
\end{tabular}

Figure5: Flexural Test of Beam on M 20(0, 0.5\% Steel Fiber) It shows following results

1) By addition of $0.5 \%$ Steel fibers, decreases in flexural Strength of fiber by $\mathbf{9 . 3 5 \%}$ for 28 days

2) By addition of $0.2 \%$ Glass fibers, increases in flexural Strength of fiber by $\mathbf{5 . 9 6} \%$ for 28 days.

\section{Conclusions}

The study on the effect of fibers with different sizes and properties can still be a promising work as there is always a need to overcome the problem of brittleness of concrete. 


\section{International Journal of Science and Research (IJSR) \\ ISSN (Online): 2319-7064}

Index Copernicus Value (2013): 6.14 | Impact Factor (2015): 6.391

The paper concluded that the addition of steel fibers at $0.5 \%$ by volume of concrete reduces the cracks under different loading conditions.

The brittleness of concrete can also be improved by addition steel fibers than glass fibers. Since concrete is very weak in tension, the steel fibers are beneficial in axial-tension to increase tensile strength.

The following conclusions could be drawn from the present investigation.

1. Max compressive strength for M20 grade of concrete was obtained by addition of $0.5 \%, 50 \mathrm{~mm}$ length, hook end steel fibers.

2. Max split tensile strength for M20 grade of concrete was obtained by addition of $0.5 \%, 50 \mathrm{~mm}$ length, hook end steel fibers.

3. Ratio of compressive strength of cylinders to the compressive strength of cube was found to be nearly $3: 4$.

4. Workability of concrete affected by addition of fibers. Addition of S2 fiber reduces workability of concrete in comparison to other fibers for different volume fraction.

5. It was found that while using glass fiber in SplitTensile test the crack width goes on reducing with increasing of fiber Dose.

6. It was found that in flexural Test the deflection goes on reducing with increasing of Fiber dose but Glass fiber having better flexural Strength than Steel fiber

\section{References}

[1] P. N. Balaguru and S. P. Shah, "Fiber Reinforced Cement Composites", McGraw-Hill Inc; 1992.

[2] N. Banthia,"Crack Growth Resistance of Hybrid Fiber Composites", Cem. Con. Comp., Volume 25, Issue 1, Pp. 3-9, 2003

[3] A. Bentur and S. Mindess, "Fibre Reinforced Cementitious Composites", Elsevier Applied Science, London, UK. 1990

[4] V. Vairagade and K. Kene, "Experimental Investigation on Hybrid Fiber Reinforced concrete", International Journal of Engineering Research and Applications, Volume 2, Issue 3, Pp. 1037-1041, 2012.

[5] A. Shende and A. Pande, "Comparative study on Steel Fiber Reinforced Cum Control Concrete", International Journal of Advanced Engineering Sciences and Technologies, Volume 6, Issue 1, Pp. 116-120, 2011.

[6] Byung Hwan Oh, "Flexural Analysis of Reinforced Concrete Beams Containing Steel Fibers", Journal of Structural Engineering, ASCE, Volume 118, Issue 10, Pp. 2821-2836, 1992.

[7] J. Barros and J. Figueiras, "Flexural Behavior of SFRC, testing and Modeling”, Journal of Materials in Civil Engineering, Volume 11, Issue 4, Pp. 273-366, 1992.

[8] S. Chen, "Strength of steel fiber reinforced concrete ground slabs", structures and Buildings Issue SB2, Pp. 157-163, 2004.

[9] H. Dwarakanath and T. Nagaraj," Comparative Study of Predictions of Flexural Strength of Steel Fiber Concrete", ACI Materials Journal, Volume 88, Issue 73, Pp.49-58, 1991.
[10] J. James and Beaudoin, "Handbook of Fiber Reinforced Concrete; principles, properties, Development and Applications", Noyes Publications, New Jersey, United State of America, Pp.57-63, 1990

[11]A. Shende, A. Pande and M. Gulfam Pathan, "Experimental Study on Steel Fiber Reinforced Concrete for M-40 Grade", International Refereed Journal of Engineering and Science, Volume 1, Issue 1, Pp. 043-048, 2012.

[12] IS 5816-1999, Method of Test for Splitting Tensile Strength of Concrete., Bureau of Indian Standards, New Delhi, India, 1999.

[13]IS 8112:1989, 43 Grade Ordinary Portland Cement Specification (First Revision), Bureau of Indian Standards, New Delhi, India, 1989.

[14]IS: 516-1959, Indian standard methods of tests for strength of concrete, Bureau of Indian Standards, New Delhi, India, 1959

[15] R Swamy, A Saad, "Deformation and Ultimate Strength in Flexural of Reinforced Concrete Beams Made with Steel Fiber Concrete", ACI Material Journal, Volume 78, Issue 5, Pp. 673-684, 1981 